\title{
Susceptibility of Thermo- Mechanically Modified Scots Pine (Pinus Sylvestris L.) Sapwood and Heartwood to Colour Change under the Influence of Ultraviolet Radiation
}

\section{Osjetljivost termo-mehanički modificiranog drva srži i bjeljike običnog bora (Pinus sylvestris L.) na promjenu boje pod utjecajem ultraljubičastog zračenja}

\author{
Original scientific paper • Izvorni znanstveni rad \\ Received-prispjelo: 29. 8. 2017. \\ Accepted-prihvaćeno: 13. 6. 2018. \\ UDK: $630 * 812.111 ; 630 * 812.463 ; 674.032 .475 .4$ \\ doi:10.5552/drind.2018.1756
}

\begin{abstract}
The impact of ultraviolet radiation on the colour of thermo-mechanically modified sapwood and heartwood of pine (Pinus sylvestris L.) was examined in the study. Samples of wood were densified in a hydraulic press at unit pressure of $80 \mathrm{MPa}$, at three levels of temperature of the press platens: $100{ }^{\circ} \mathrm{C}, 150{ }^{\circ} \mathrm{C}$ and 200 ${ }^{\circ} \mathrm{C}$, for $360 \mathrm{~s}$. The parameters of wood colour were determined using the mathematical colour space models CIE $L^{*} a * b^{*}$ and $L^{*} C^{*} h$. As a result of the modification of pine sapwood at the temperature of $200{ }^{\circ} C$, the change in wood colour $\triangle E$ was twice as substantial as the change in wood colour after modifications at lower temperatures. The total colour difference for pine heartwood, irrespective of the modification temperature, was at least twice as substantial as the change in the colour of pine sapwood. The most substantial changes in sapwood and heartwood lightness occurred after 20 h exposure to UV radiation. Changes in lightness occurring within 20 h, irrespective of the temperature of treatment, accounted for about $30-60 \%$ of the total change. After 300 h of irradiation, the value of $\triangle E$ for sapwood densified at temperatures of $100{ }^{\circ} \mathrm{C}, 150{ }^{\circ} \mathrm{C}$ and $200{ }^{\circ} \mathrm{C}$ was, respectively, $15 \%, 27 \%$ and $34 \%$ higher than the value of $\triangle E$ for heartwood densified at the same temperatures.
\end{abstract}

Keywords: colour, densification, heartwood, sapwood, Scots pine, thermo-mechanical modification

SAŽETAK・U studiji je istražen utjecaj ultraljubičastog (UV) zračenja na boju termo-mehanički modificiranog drva bjeljike i srži običnog bora (Pinus sylvestris L.). Uzorci drva izloženi su procesu ugušćivanja u hidrauličkoj

\footnotetext{
${ }^{1}$ Author is an assistant professor at Faculty of Wood Technology, Warsaw University of Life Sciences - SGGW, Warsaw, Poland.

${ }^{1}$ Autorica je docentica Fakulteta drvne tehnologije, Sveučilište bioloških znanosti u Varšavi (SGGW), Varšava, Poljska.
} 
preši jediničnog tlaka $80 \mathrm{MPa}$ i pri tri različite temperature: 100,150 i $200{ }^{\circ} \mathrm{C}$ tijekom 360 sekunda. Parametri boje drva određeni su uz pomoć matematičkih modela prostora boja CIE $L^{*} a^{*} b^{*} i L^{*} C^{*} h$. Kao posljedica modifikacije drva bjeljike običnog bora pri temperaturi $200{ }^{\circ} \mathrm{C}$ promjena boje drva bila je dvostruko veća nego pri modifikaciji na nižim temperaturama. Ukupna razlika u boji uzoraka od srži običnog bora, bez obzira na temperaturu modifikacije, bila je dva puta veća od promjene boje na uzorcima od drva bjeljike. Najveće promjene svjetline uzoraka od drva srži i bjeljike običnog bora nastale su nakon 20 sati izlaganja UV zračenju. Promjene svjetline koje se pojavljuju nakon 20 sati izlaganja UV zračenju, bez obzira na temperaturu modifikacije, činile su oko 30 $60 \%$ ukupne promjene svjetline. Nakon 300 sati UV zračenja vrijednost $\Delta E$ za uzorke od drva bjeljike podvrgnute procesu ugušćivanja pri temperaturama 100, 150 i 200 ${ }^{\circ}$ C bila je 15, 27 i $34 \%$ veća od vrijednosti $\Delta E$ za uzorke od drva srži podvrgnute ugušćivanju pri jednakim temperaturama.

Ključne riječi: boja, proces ugušćivanja, srž, bjeljika, obični bor, termo-mehanička modifikacija

\section{INTRODUCTION}

\section{UVOD}

The colour of wood is an effect of the selective reflection and diffusion of light rays with wavelength characteristic of a given material. A material has a colour corresponding to the spectral composition of reflected and diffused rays. It absorbs the remaining rays forming part of the spectral composition, so they do not reach the eye and do not give the impressions of colour. One of the characteristic features of wood is the changeability of colour. The colour of wood depends on a number of external factors, among which climatic conditions play the most significant role (Hon and Minemura, 1991; Sharratt et al., 2009; Tolvaj and Mitsui, 2010). Tolvaj and Mitsui (2010) found that colour alteration of black locust wood can be seen by the naked eye after 2-3 h of solar irradiation. Sharratt et al. (2009) showed that the majority of colour changes of Scots pine (Pinus sylvestris L.) occurred within the first $24 \mathrm{~h}$ after simulated accelerated sunlight exposure. The colour of wood also depends on habitat conditions. Depending on the type and content of extractives, particular wood species show different susceptibility to colour change under the influence of ultraviolet radiation (Pandey, 2005; Persze and Tolvaj, 2012; Moya, et al. 2012).

Some wood species are capable of forming coloured heartwood. The oldest annual growth rings, located most closely to the pith, change their chemical composition and have limited water permeability. Heartwood is often darker in colour compared to sapwood, which makes it possible to distinguish it with the naked eye. Heartwood only fulfils a mechanical role. It strengthens the trunk, and this part of the trunk becomes naturally impregnated during the life of the tree and it is more resistant to microorganisms and insects than sapwood. Sapwood, in addition to strengthening the trunk, participates in the plant's vital functions, e.g. water transmission and accumulation of nutrients, and for this reason it is definitely more susceptible to rots and insects feeding. In extreme cases, e.g. in the case of common oak wood, sapwood, which is usually narrow, is treated as waste, a part of the trunk that is not suitable for processing. Pine wood is a heartwood species with coloured heartwood. The sapwood component in pine wood is considerable and may reach up to $1 / 3$ of the trunk width. Similarly to heartwood, pine sapwood is used for industrial purposes. Pine sapwood is light yellow, whereas heartwood is red-brown. The darker colour of heartwood is caused by the presence of gum, tannins, dye substances and other extractives (Wagenführ, 2007).

Thermo-mechanical modification is one of the methods enabling the improvement of physical and mechanical properties of wood without the use of chemicals (Ülker et al., 2012; Rautkari et al., 2013; Laskowska, 2017). The following features are most frequently described as quality indicators of densified wood: density, hardness, dimensional stability (Ülker et al., 2012; Laine et al., 2013, 2016; Rautkari et al., 2013; Tu et al., 2014). There is no comprehensive data on the impact of abiotic factors, i.e. ultraviolet radiation, on the colour of wood subjected to densification. Neither is there comprehensive data concerning colour changes in densified wood broken down into sapwood and heartwood areas. Wood colour stability is an important feature, since it is among the primary factors determining the usability of wood. Moreover, it may constitute an indirect indicator of wood quality and strength (Bekhta and Niemz, 2003; Johansson and Morén, 2006; González-Peña and Hale, 2009).

The purpose of the study was to determine the impact of ultraviolet radiation on the colour of thermo-mechanically modified sapwood and heartwood of pine (Pinus sylvestris L.). A particularly important aspect was to determine the change in the colour parameters of wood in time. Another important aspect was to verify the differences in the susceptibility of pine sapwood and heartwood to colour change under the influence of ultraviolet radiation.

\section{MATERIALS AND METHODS} 2. MATERIJALI I METODE

Pine (Pinus sylvestris L.) sapwood (S) and heartwood $(\mathrm{H})$ from a forest in the central Poland, managed by the State Forests National Forest Holding, were used for the study. The samples used for the study had the dimensions of $120 \mathrm{~mm}$ (longitudinal), $60 \mathrm{~mm}$ (radial) x $5 \mathrm{~mm}$ (tangential). 20 samples were used for each variant of thermo-mechanical modification and exposed to light irradiation. The surface of samples was finished by planing. The samples were conditioned for three months in a normal climate (temperature 20 ${ }^{\circ} \mathrm{C} \pm 2{ }^{\circ} \mathrm{C}$, relative humidity $65 \% \pm 5 \%$ ).

The thermo-mechanical modification of wood was conducted in a laboratory hydraulic press. The tempera- 
ture of the press platens was $100^{\circ} \mathrm{C}, 150{ }^{\circ} \mathrm{C}$ and $200^{\circ} \mathrm{C}$, while the unit pressure was $80 \mathrm{MPa}$. The thermo-mechanical modification of wood included three stages: (1) heating wood samples for $180 \mathrm{~s}$ with the closed press platens without exerting pressure, (2) pressing at the assumed pressure for $180 \mathrm{~s}$, (3) cooling wood samples in an unheated hydraulic press without exerting pressure. The cooling process was carried out until wood achieved the temperature of approximately $70{ }^{\circ} \mathrm{C}$.

Four fluorescent lamps were used for ultraviolet radiation, each with a capacity of 100W (model 100R, LIGHTECH company, Poland). Wood samples were subjected to ultraviolet radiation within a spectrum range of $340-360 \mathrm{~nm}$. The used source of radiation was imitating the solar radiation, in particular the UVA component. In studies by other authors, a strong UV light emitter, i.e. a mercury vapour lamp with total light emission of $320 \mathrm{~W}$, was used for wood light irradiation (Tolvaj and Mitsui, 2010). Wood samples were subjected to ultraviolet radiation within a spectrum range of $300-400 \mathrm{~nm}$. Wood samples were light irradiated for $300 \mathrm{~h}$, and colour parameters were determined after each subsequent $20 \mathrm{~h}$ of irradiation. 20 samples were used for studying colour for each variant of non-densified and densified wood. Colour parameters were examined at three measurement points for each sample.

Wood moisture was determined in accordance with ISO 13061-1 (2014) requirements, and density in accordance with ISO 13061-2 (2014). Wood moisture was $7.82 \%( \pm 0.13)$. The compression ratio $(C R)$ was calculated according to Eq. 1, where $t_{\mathrm{o}}$ is the original thickness $(\mathrm{mm})$, and $t_{\mathrm{d}}$ is wood thickness after densification $(\mathrm{mm})$.

$$
C R=\frac{t_{0}-t_{d}}{t_{0}} \cdot 100(\%)
$$

The following colour parameters were determined: lightness $\left(L^{*}\right)$, chromatic coordinate on the redgreen axis $\left(a^{*}\right)$, chromatic coordinate on the yellowblue axis $\left(b^{*}\right)$, saturation $\left(C^{*}\right)$ and hue angle $(h)$. The total colour difference $\Delta E$ was determined according to ISO 7724-3 (1984). SP60 spectrophotometer made by X-Rite Europe GmbH (Regensdorf, Switzerland) was used to examine the colour parameters. The sensor head was $8 \mathrm{~mm}$ in diameter. Measurements were made using a D65 illuminant.

Statistical analysis of the results was performed using STATISTICA Version-12 software of StatSoft, Inc. (Tulsa, USA). The statistical analysis of the results was performed at a significance level of 0.05 . The trend lines were determined, and parameters of the curve equation $(y)$ were specified along with the coefficients of determination $R^{2}$ for correlations describing the change in pine wood colour parameters in time.

\section{RESULTS AND DISCUSSION}

\section{REZULTATI I RASPRAVA}

The influence of the area of wood (sapwood, heartwood) and of densification temperature (based on ANOVA, Fischer's $F$ - test) on the parameters of densified wood was shown in Table 1. It was also specified to what extent the factors under analysis affected the wood colour parameters immediately after the modification (parameters identified by the symbol M, e.g. $L^{*} \_\mathrm{M}$ ) and after $300 \mathrm{~h}$ of light irradiation of wood (parameters identified by the symbol $\mathrm{R}$, e.g. $L^{*} \mathrm{R}_{\text {). The }}$ influence of the area of wood and temperature of treatment on the colour change $\Delta E$ after $20 \mathrm{~h}$ and $300 \mathrm{~h}$ of light irradiation was analysed (marked as $\Delta E \_20 \mathrm{R}$ and $\Delta E \_300 \mathrm{R}$, respectively).

The wood area (sapwood, heartwood) demonstrated a significant influence on all the pine properties under study except for density. The degree of densification of sapwood was so high that comparable densities were achieved for sapwood and heartwood as a result of modification. The temperature of thermo-mechanical modification showed a significant influence on all pine wood properties under study $(p<0.05)$. The interaction between the area of densified wood and the temperature of treatment, which shaped the wood parameters under study except for $a^{*}$ and $h$ after light irradiation, was also significant. When analysing the percentage impact of factors on the properties of densified pine wood under study, considerable differences in the effect of these factors could be noted. The temperature of treatment influenced the values of $C R$ and density (influence at a level of $98 \%$ ), $b^{*}$ and $\Delta E$ (influence at a level of $44-63 \%$ ) to a much greater extent than the area of the densified wood. The differences between sapwood and heartwood determined primarily the values of $L^{*}, a^{*}, h$, both immediately after densification, and after light irradiation (influence at a level of $50-84 \%$ ). The level of influence of the factors under analysis on colour parameters was different after light irradiation than immediately after densification. When the influence of the wood area increased, the influence of the temperature decreased and vice versa. For example, the wood area influenced the differences in the lightness of wood to a greater extent after light irradiation than immediately after densification (the influence of this factor increased from $50 \%$ to $76 \%$ ), whereas the influence of the temperature of treatment on the lightness of wood after light irradiation (12\%) was smaller than after densification (32\%).

The present studies show that the higher the temperature of the press platen, the higher degree of compression of pine sapwood and heartwood and, consequently, the higher density, was achieved. Pine heartwood was compressed to a lesser degree than sapwood (Figure 1a). This was due to the lesser susceptibility of latewood zones in heartwood to densification. Heartwood latewood is characterised by greater density and it is often saturated with resin which, by filling the interior of cells, makes their densification difficult. Pine heartwood may contain even five times as much resin as sapwood (Sandermann and Augustin, 1963).

As a result of greater compression, the density of sapwood became comparable to the density of heartwood (Figure 1b). The density of non-densified pine sapwood and heartwood was $466 \mathrm{~kg} \cdot \mathrm{m}^{-3}( \pm 17)$ and 558 $\mathrm{kg} \cdot \mathrm{m}^{-3}( \pm 9)$, respectively. This value was comparable to values cited in the literature. According to Wagen- 
Table 1 Statistical evaluation of factors influencing parameters of thermo-mechanically densified pine wood

Tablica 1. Statistička procjena čimbenika koji utječu na svojstva termo-mehanički ugušćenog drva običnog bora

\begin{tabular}{|c|c|c|c|c|c|c|}
\hline \multirow{4}{*}{$\begin{array}{l}\text { Factor } \\
\text { Čimbenik }\end{array}$} & \multicolumn{6}{|c|}{ Properties / Svojstva } \\
\hline & \multicolumn{3}{|c|}{ Compression ratio / Omjer kompresije } & \multicolumn{3}{|c|}{ Density / Gustoća } \\
\hline & $\begin{array}{c}\text { Fisher's } \\
\text { F-test } \\
\text { Fisherov F-test }\end{array}$ & $\begin{array}{c}\text { Significance } \\
\text { level } \\
\text { Razina } \\
\text { značajnosti } \\
\end{array}$ & $\begin{array}{c}\text { Factor Influence } \\
\text { Utjecaj čimbenika } \\
\%\end{array}$ & $\begin{array}{c}\text { Fisher's } \\
\text { F-test } \\
\text { Fisherov F-test }\end{array}$ & $\begin{array}{c}\text { Significance } \\
\text { level } \\
\text { Razina } \\
\text { značajnosti } \\
\end{array}$ & $\begin{array}{c}\text { Factor Influence } \\
\text { Utjecaj } \\
\text { čimbenika } \\
\% \\
\end{array}$ \\
\hline & $\mathrm{F}$ & $\mathrm{p}$ & $\mathrm{X}$ & $\mathrm{F}$ & $\mathrm{p}$ & $\mathrm{X}$ \\
\hline Wood area (1) & 357.62 & 0.000000 & 1 & 1.1 & 0.295394 & 0 \\
\hline Temp. (2) & 9264.44 & 0.000000 & 98 & 3455.5 & 0.000000 & 98 \\
\hline$(1) \times(2)$ & 54.38 & 0.000000 & 1 & 38.3 & 0.000000 & 1 \\
\hline \multirow[t]{3}{*}{ Error } & & & 0 & & & 1 \\
\hline & $L^{*}{ }_{2} \mathbf{M}$ & & & $L * \mathrm{R}^{*}$ & & \\
\hline & $\mathrm{F}$ & $\mathrm{p}$ & $\mathrm{X}$ & $\mathrm{F}$ & $\mathrm{p}$ & $\mathrm{X}$ \\
\hline Wood area (1) & 341.1 & 0.000000 & 50 & 581.2 & 0.000000 & 76 \\
\hline Temp. (2) & 72.7 & 0.000000 & 32 & 31.6 & 0.000000 & 12 \\
\hline$(1) \times(2)$ & 14.9 & 0.000000 & 7 & 4.8 & 0.004187 & 2 \\
\hline \multirow[t]{3}{*}{ Error } & & & 11 & & & 10 \\
\hline & $a^{*}{ }_{-} \mathrm{M}$ & & & $a^{*} \_\mathrm{R}$ & & \\
\hline & $\mathrm{F}$ & $\mathrm{p}$ & $\mathrm{X}$ & $\mathrm{F}$ & $\mathrm{p}$ & $\mathrm{X}$ \\
\hline Wood area (1) & 631.420 & 0.000000 & 69 & 448.06 & 0.000000 & 83 \\
\hline Temp. (2) & 58.979 & 0.000000 & 19 & 5.21 & 0.002590 & 3 \\
\hline$(1) \times(2)$ & 10.743 & 0.000006 & 4 & 1.24 & 0.299904 & 1 \\
\hline \multirow[t]{3}{*}{ Error } & & & 8 & & & 13 \\
\hline & $b^{*}{ }_{-} \mathbf{M}$ & & & $b^{*} \_\mathrm{R}$ & & \\
\hline & $\mathrm{F}$ & $\mathrm{p}$ & $\mathrm{X}$ & $\mathrm{F}$ & $\mathrm{p}$ & $X$ \\
\hline Wood area (1) & 273.47 & 0.000000 & 36 & 13.0 & 0.000571 & 5 \\
\hline Temp. (2) & 114.11 & 0.000000 & 46 & 57.4 & 0.000000 & 63 \\
\hline$(1) \times(2)$ & 20.84 & 0.000000 & 8 & 4.7 & 0.004495 & 5 \\
\hline \multirow[t]{3}{*}{ Error } & & & 10 & & & 27 \\
\hline & $\Delta E \_20 \mathrm{R}$ & & & $\Delta E \_300 \mathrm{R}$ & & \\
\hline & $\mathrm{F}$ & $\mathrm{p}$ & $\mathrm{X}$ & $\mathrm{F}$ & $\mathrm{p}$ & $X$ \\
\hline Wood area (1) & 6.799 & 0.011080 & 3 & 34.871 & 0.000000 & 10 \\
\hline Temp. (2) & 38.806 & 0.000000 & 44 & 67.734 & 0.000000 & 60 \\
\hline$(1) \times(2)$ & 23.156 & 0.000000 & 26 & 9.315 & 0.000028 & 8 \\
\hline \multirow[t]{3}{*}{ Error } & & & 27 & & & 22 \\
\hline & $C^{*} \_\mathrm{M}$ & & & $C^{*} \_\mathrm{R}$ & & \\
\hline & $\mathrm{F}$ & $\mathrm{p}$ & $\mathrm{X}$ & $\mathrm{F}$ & $\mathrm{p}$ & $X$ \\
\hline Wood area (1) & 345.01 & 0.000000 & 42 & 19.8 & 0.000031 & 8 \\
\hline Temp. (2) & 115.38 & 0.000000 & 42 & 47.9 & 0.000000 & 58 \\
\hline$(1) \times(2)$ & 21.23 & 0.000000 & 8 & 3.6 & 0.017797 & 4 \\
\hline \multirow[t]{3}{*}{ Error } & & & 8 & & & 30 \\
\hline & $h \_\mathrm{M}$ & & & $h \_\mathrm{R}$ & & \\
\hline & $\mathrm{F}$ & $\mathrm{p}$ & $\mathrm{X}$ & $\mathrm{F}$ & $\mathrm{p}$ & $X$ \\
\hline Wood area (1) & 522.0 & 0.000000 & 77 & 521.4 & 0.000000 & 84 \\
\hline Temp. (2) & 24.5 & 0.000000 & 11 & 7.6 & 0.000167 & 4 \\
\hline$(1) \times(2)$ & 4.1 & 0.010082 & 2 & 1.2 & 0.300333 & 1 \\
\hline Error & & & 10 & & & 11 \\
\hline
\end{tabular}

führ (2007), pine wood (Pinus sylvestris L.) density in an air-dry condition ranges from $330 \mathrm{~kg} \cdot \mathrm{m}^{-3}$ to 890 $\mathrm{kg} \cdot \mathrm{m}^{-3}$, with the mean value of $510 \mathrm{~kg} \cdot \mathrm{m}^{-3}$. The mean density after thermo-mechanical modification ranged from $986 \mathrm{~kg} \cdot \mathrm{m}^{-3}$ to $1126 \mathrm{~kg} \cdot \mathrm{m}^{-3}$ for sapwood and from $1023 \mathrm{~kg} \cdot \mathrm{m}^{-3}$ to $1068 \mathrm{~kg} \cdot \mathrm{m}^{-3}$ for heartwood. Generally, it can be concluded that thermo-mechanical modification resulted in twice as high density of pine sapwood and heartwood. Laine et al. (2016) densified Scots pine (Pinus sylvestris L.) sapwood at $150{ }^{\circ} \mathrm{C}$ for $1 \mathrm{~h}$. The highest density they obtained by densifying $12.5 \mathrm{~mm}$ thick samples was $915 \pm 25.7 \mathrm{~kg} \cdot \mathrm{m}^{-3}$ (the densification ratio was $50 \%$ ).

\subsection{Pine wood colour parameters after thermo-} mechanical modification

3.1. Parametri boje drva bora nakon termo-mehaničke modifikacije

The thermo-mechanical modification of pine sapwood and heartwood at temperatures of $100{ }^{\circ} \mathrm{C}$ and $150^{\circ} \mathrm{C}$ caused slight changes in the colour lightness of wood, only just noticeable to the naked eye. Only treatment at a temperature of $200{ }^{\circ} \mathrm{C}$ resulted in a clear 


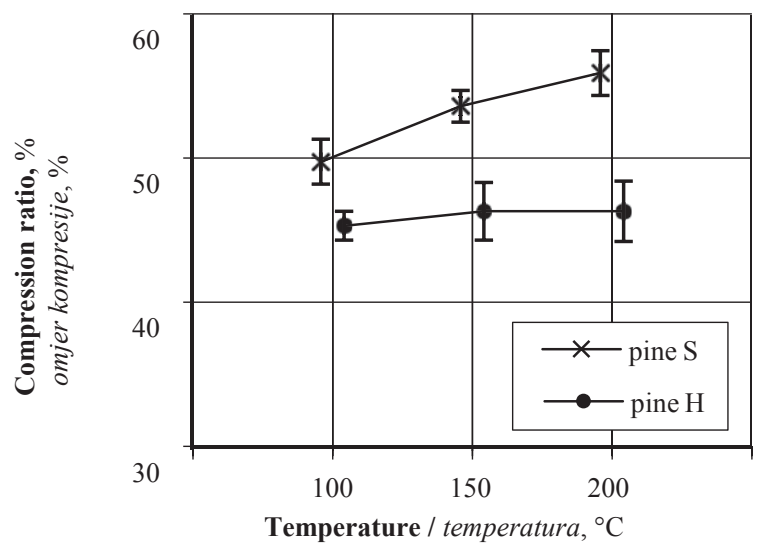

a)

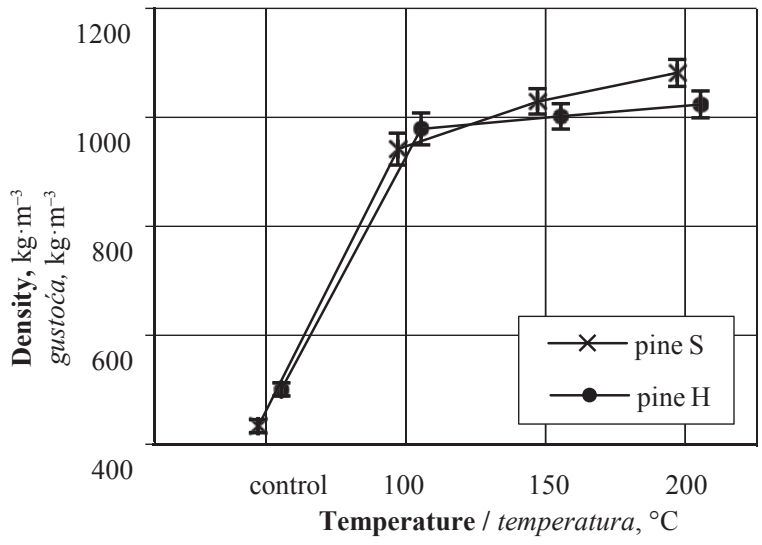

b)

Figure 1 Compression ratio (a) and density (b) of densified pine wood

Slika 1. a) Omjer kompresije, b) gustoća ugušćenog drva bora u ovisnosti o temperaturi tijekom procesa ugušćivanja

change in colour. Similar correlations were found by Bekhta et al. (2014), who examined the effect of short-term thermo-mechanical (STTM) densification temperature and pressure on the surface colour of veneer of alder, beech, birch and pine. The authors do not specify whether they examined pine sapwood or heartwood. A decrease in the lightness of wood, as a result of treatment, is caused by the degradation of hemicelluloses, whereby the greater the degradation of hemicelluloses, the higher is the temperature of heat treatment. As a result, the lignin content in wood increases, giving wood a darker colour (Diouf et al., 2011; Bekhta et al., 2014).

The densification of pine sapwood at temperatures of $100{ }^{\circ} \mathrm{C}$ and $150{ }^{\circ} \mathrm{C}$ did not influence, to a significant extent, the values of $a^{*}$ and $b^{*}$ and, consequently, did not contribute to the total colour difference $\Delta E$. As a result, the changes in the value of $\Delta E$ (at a level of ca. 3.5) were comparable for pine sapwood densified at temperatures of $100{ }^{\circ} \mathrm{C}$ and $150{ }^{\circ} \mathrm{C}$ (Table 2). The most significant changes in wood colour towards red occurred at a modification temperature of $200{ }^{\circ} \mathrm{C}$, both in case of sapwood and heartwood. As the modification temperature of sapwood and heartwood increased, the saturation of colour $C^{*}$ increased and the value of $\mathrm{h}$ decreased. A change in colour towards red may be due to the presence of extractives in wood (Bekhta et al., 2014). As heartwood contains more extractives, it was more susceptible to colour change towards red than sapwood. According to Waliszewska et al. (2015), as obtained by Soxhlet extraction with ethanol, the extractive content in the sapwood of a 75-year old pine tree ranges from 2.3 to $2.7 \%$, and in its heartwood from 6.8 $\%$ to $13.3 \%$. An increase in the yellow component could also be observed with the increase of modification temperature in case of heartwood that contained more lignin. The factors accountable for the wood becoming yellow include primarily lignin and its derivatives, i.e. quinones and stilbenes (Hon and Glasser, 1979). The value of $b^{*}$ for sapwood and heartwood modified at a

Table 2 Pine wood colour parameters after thermo-mechanical modification (standard deviations in parentheses)

Tablica 2. Parametri boje drva bora nakon termo-mehaničke modifikacije (u zagradama su standardna odstupanja)

\begin{tabular}{|c|c|c|c|c|c|c|c|}
\hline \multirow{2}{*}{$\begin{array}{l}\text { Area } \\
\text { Površina }\end{array}$} & \multirow{2}{*}{$\begin{array}{c}\text { Densification temperature } \\
\text { Temperatura u procesu } \\
\text { ugušćivanja } \\
{ }^{\circ} \mathrm{C}\end{array}$} & \multicolumn{6}{|c|}{ Parameters / Parametri } \\
\hline & & $L^{*}$ & $a^{*}$ & $b^{*}$ & $\Delta \mathrm{E}$ & $C^{*}$ & $h$ \\
\hline \multirow{4}{*}{$\begin{array}{l}\text { pine sapwood } \\
\text { bjeljika drva } \\
\text { bora }\end{array}$} & $\begin{array}{c}\text { Control } \\
\text { kontrolni uzorak }\end{array}$ & $\begin{array}{c}81.32 \\
( \pm 2.04)\end{array}$ & $4.48( \pm 0.82)$ & $\begin{array}{c}23.91 \\
( \pm 0.44)\end{array}$ & - & $\begin{array}{c}24.34 \\
( \pm 0.50)\end{array}$ & $\begin{array}{c}79.41 \\
( \pm 1.85)\end{array}$ \\
\hline & 100 & $\begin{array}{c}80.96 \\
( \pm 0.67)\end{array}$ & $4.52( \pm 0.37)$ & $\begin{array}{c}26.41 \\
( \pm 0.86)\end{array}$ & $3.35( \pm 0.42)$ & $\begin{array}{c}27.16 \\
( \pm 0.90)\end{array}$ & $\begin{array}{c}80.90 \\
( \pm 0.54)\end{array}$ \\
\hline & 150 & $\begin{array}{c}80.45 \\
( \pm 0.54)\end{array}$ & $4.65( \pm 0.32)$ & $\begin{array}{c}26.58 \\
( \pm 0.99)\end{array}$ & $3.56( \pm 0.38)$ & $\begin{array}{c}27.93 \\
( \pm 1.02)\end{array}$ & $\begin{array}{c}80.79 \\
( \pm 0.41)\end{array}$ \\
\hline & 200 & $\begin{array}{c}77.15 \\
( \pm 1.50)\end{array}$ & $6.47( \pm 0.56)$ & $\begin{array}{c}28.83 \\
( \pm 1.55)\end{array}$ & $6.91( \pm 1.05)$ & $\begin{array}{c}29.55 \\
( \pm 1.57)\end{array}$ & $\begin{array}{c}77.33 \\
( \pm 0.98)\end{array}$ \\
\hline \multirow{4}{*}{$\begin{array}{l}\text { pine } \\
\text { heartwood } \\
\text { srž drva bora }\end{array}$} & $\begin{array}{c}\text { Control } \\
\text { kontrolni uzorak }\end{array}$ & $\begin{array}{c}77.66 \\
( \pm 1.48)\end{array}$ & $7.37( \pm 0.88)$ & $\begin{array}{c}25.56 \\
( \pm 0.62)\end{array}$ & - & $\begin{array}{c}26.61 \\
( \pm 0.77)\end{array}$ & $\begin{array}{r}73.96 \\
( \pm 1.64)\end{array}$ \\
\hline & 100 & $\begin{array}{c}74.78 \\
( \pm 1.87) \\
\end{array}$ & $9.46( \pm 0.92)$ & $\begin{array}{c}30.71 \\
( \pm 2.00) \\
\end{array}$ & $6.60( \pm 0.45)$ & $\begin{array}{c}32.14 \\
( \pm 2.16) \\
\end{array}$ & $\begin{array}{c}72.89 \\
( \pm 0.78) \\
\end{array}$ \\
\hline & 150 & $73.11( \pm 1.93)$ & $9.88( \pm 0.95)$ & $\begin{array}{c}33.93 \\
( \pm 2.27) \\
\end{array}$ & $\begin{array}{c}10.63 \\
( \pm 1.36) \\
\end{array}$ & $\begin{array}{c}35.22 \\
( \pm 2.37) \\
\end{array}$ & $\begin{array}{c}72.49 \\
( \pm 1.03) \\
\end{array}$ \\
\hline & 200 & $\begin{array}{c}65.36 \\
( \pm 3.84)\end{array}$ & $\begin{array}{c}12.09 \\
( \pm 1.35)\end{array}$ & $\begin{array}{c}36.12 \\
( \pm 1.02)\end{array}$ & $\begin{array}{c}16.39 \\
( \pm 2.37)\end{array}$ & $\begin{array}{c}38.10 \\
( \pm 1.17)\end{array}$ & $\begin{array}{c}71.52 \\
( \pm 1.83)\end{array}$ \\
\hline
\end{tabular}


temperature of $200{ }^{\circ} \mathrm{C}$ was, respectively, $21 \%$ and 41 $\%$ higher than for non-modified sapwood and heartwood. The modification of pine sapwood at a temperature of $200{ }^{\circ} \mathrm{C}$ resulted in a change in wood colour $\Delta \mathrm{E}$ that was twice as substantial as the change in wood colour after modifications at lower temperatures. The densification of pine heartwood resulted in a greater difference in wood colour. The higher the modification temperature, the more substantial was the total colour difference for pine heartwood. In general, it can be concluded that the total colour difference for pine heartwood, irrespective of the modification temperature, was twice as substantial as the change in the colour of pine sapwood.

\subsection{Colour parameters of thermo-mechanically} modified pine wood after light irradiation

3.2. Parametri boje termo-mehanički modificiranog drva bora nakon izlaganja UV zračenju

Significant changes in the colour of wood under the influence of ultraviolet radiation were observed. The below analysis, based on the CIE $L^{*} a^{*} b^{*}$ and $L^{*} C^{*} h$ systems, provides the detailed characteristics of wood colour.

Pine sapwood was characterised by lesser susceptibility to a change in lightness $L^{*}$ under the influence of ultraviolet radiation than heartwood. The difference between $L^{*}$ before and after light irradiation of pine sapwood was ca. 8 , whereas in the case of pine heartwood it ranged from ca. 7 to 12 . The above correlations were caused by differences in the chemical composition of wood. The factor accountable for wood darkening is lignin (Hon and Glasser, 1979; Diouf et al., 2011; Bekhta et al., 2014). Pine heartwood contains more lignin than sapwood (Waliszewska et al., 2015). Moreover, as the densification temperature increased, the degradation of hemicelluloses became more intense, which additionally contributed to the increase in the lignin percentage content in wood. As a result, the colour of pine sapwood and heartwood densified at a temperature of $200{ }^{\circ} \mathrm{C}$ was much darker than in the case of the same wood densified at temperatures of $100{ }^{\circ} \mathrm{C}$ and $150{ }^{\circ} \mathrm{C}$. This confirms mechanisms involved in the thermal decomposition of wood components. Kollmann and Fengel (1965) heated oak and pine wood at different temperatures. The authors found that pine lost weight at about $100{ }^{\circ} \mathrm{C}$, whilst oak remained stable to about $130^{\circ} \mathrm{C}$. Additionally, it should be noted that wood densified at a higher temperature changed its $L^{*}$ under the influence of light irradiation to a lesser extent. Within $300 \mathrm{~h}$, the value of $L^{*}$ for pine sapwood and heartwood densified at temperatures of $100{ }^{\circ} \mathrm{C}$ and $150{ }^{\circ} \mathrm{C}$ decreased by $12 \%$, whereas pine sapwood and heartwood densified at a temperature of $200{ }^{\circ} \mathrm{C}$ recorded a decrease of $9 \%$. The study showed that the most substantial changes in wood lightness occurred after $20 \mathrm{~h}$ exposure to UV radiation, both for
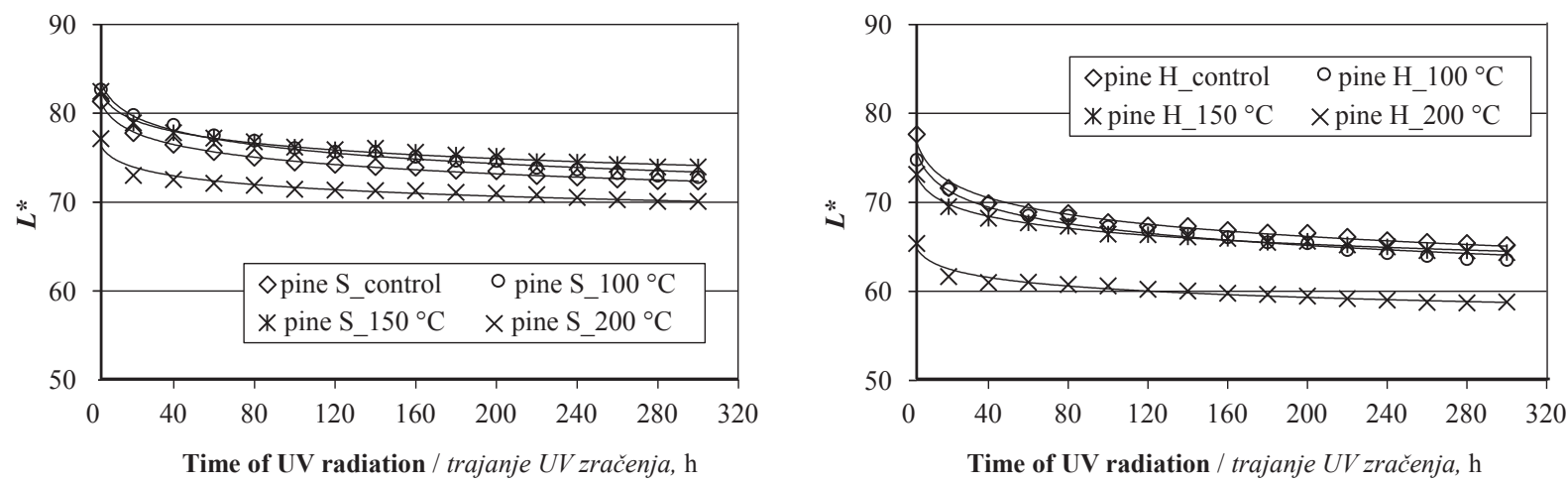

a)

b)

Figure 2 Change of lightness $\left(L^{*}\right)$ of pine sapwood (a) and heartwood (b) after exposure to UV radiation Slika 2. Promjena svjetline $\left(L^{*}\right)$ : a) bjeljike, b) srži drva bora nakon izlaganja UV zračenju

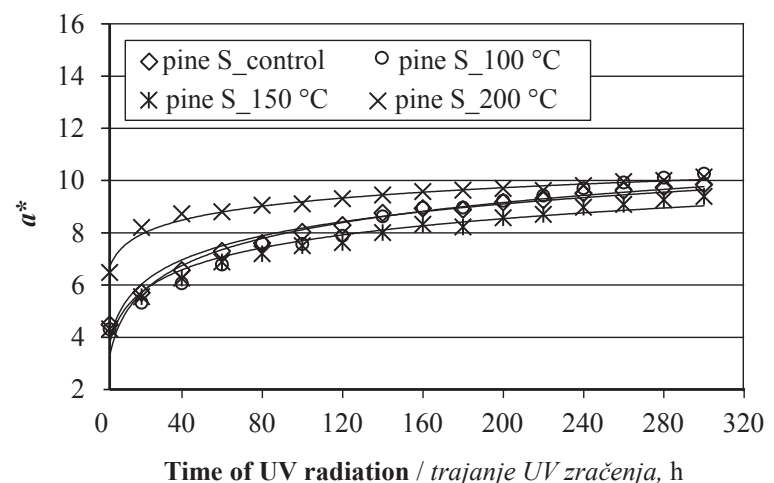

a)

Slika 3. Promjena parametra $a^{*}$ : a) bjeljike, b) srži drva bora nakon izlaganja UV zračenju 


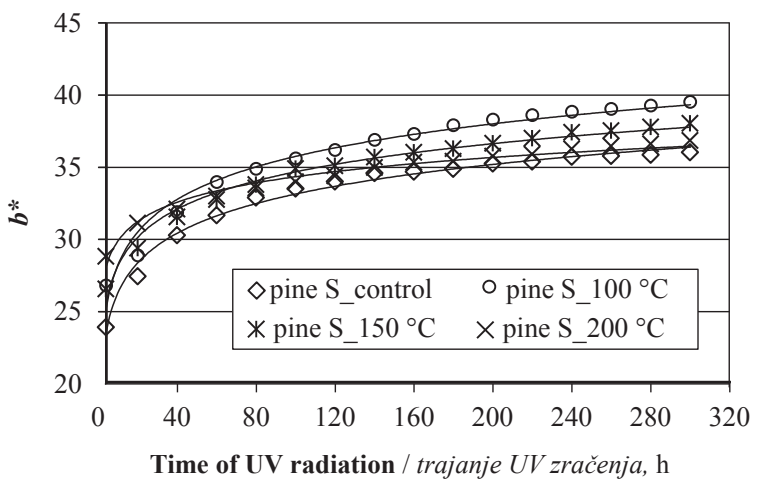

a)

Figure 4 Change in $b^{*}$ parameter of pine sapwood (a) and heartwood (b) after exposure to UV radiation

Slika 4. Promjena parametra $b^{*}$ : a) bjeljike, b) srži drva bora nakon izlaganja UV zračenju

sapwood and heartwood (Figure 2). Changes in lightness occurring within $20 \mathrm{~h}$, irrespective of the temperature of treatment, accounted for about $30-60 \%$ of the total change in pine sapwood and heartwood. Tolvaj and Mitsui (2010) also found that the most substantial changes in the lightness of black locust, beech, Japanese cedar and spruce wood occurred during the first $20 \mathrm{~h}$ of sun light irradiation.

As a result of light irradiation, pine wood changed colour towards red (Figure 3). The value of $a^{*}$, after $300 \mathrm{~h}$ of light irradiation, was double for non-densified sapwood and heartwood compared with its value before light irradiation. After $300 \mathrm{~h}$ of light irradiation, the value of $a^{*}$ was 1.5 times higher for heartwood (non-densified and densified) than for sapwood. Heartwood changed its parameter $a^{*}$ under the influence of light irradiation to a lesser extent than sapwood. Sapwood and heartwood, densified at a temperature of $200{ }^{\circ} \mathrm{C}$, changed their parameter $a^{*}$ under the influence of light irradiation to a considerably lesser extent than sapwood and heartwood densified at a lower temperature. After $300 \mathrm{~h}$ of light irradiation, the value of $a^{*}$ for sapwood, depending on the modification temperature, was from $60 \%$ to $140 \%$ higher than before irradiation. On the other hand, the value of $a^{*}$ for heartwood, after $300 \mathrm{~h}$ of light irradiation, was from $30 \%$ to $60 \%$ higher than before light irradiation, depending on the modification temperature. A change in colour towards red may be due to the presence of extractives in the wood (Yazaki et al., 1994; Gierlinger et al., 2004; Per-

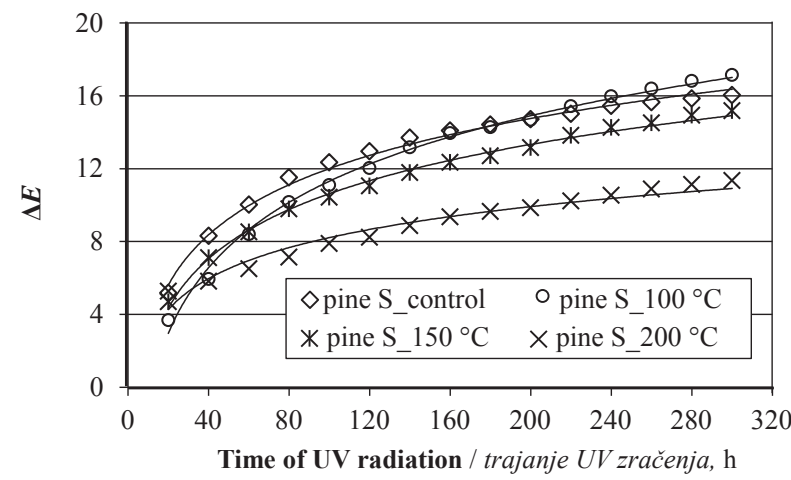

a)

Figure 5 Total colour difference $(\Delta E)$ of pine sapwood (a) and heartwood (b)

Slika 5. Ukupna promjena boje $(\Delta E)$ : a) bjeljike, b) srži drva bora sze and Tolvaj, 2012; Bekhta et al., 2014). The values of $a^{*}$ show a trend in the colour change of sapwood and heartwood towards red, due to a decrease in the hue angle, as shown in Figure 8c, d.

The colour of sapwood changed towards yellow under the influence of light irradiation to a greater extent than the colour of heartwood (Figure 4). After 300 $\mathrm{h}$ of light irradiation, the value of $a^{*}$ for sapwood, depending on the modification temperature, was from 30 $\%$ to $50 \%$ higher than before light irradiation. The value of $a^{*}$ for heartwood after $300 \mathrm{~h}$ of light irradiation, on the other hand, was from $2 \%$ to $25 \%$ higher than before light irradiation, depending on the modification temperature. The higher the modification temperature, the smaller was the change in the value of $b^{*}$ of the wood under the influence of light irradiation. Heartwood modified at $200{ }^{\circ} \mathrm{C}$ did not show a significant change in the value of $b^{*}$ under the influence of light irradiation. The values of $b^{*}$ show a trend in the colour change of sapwood and heartwood towards yellow, caused by an increased colour saturation (Figure $8 \mathrm{a}, \mathrm{b})$. Yellowing is the main colour change of wood, this being an effect of the photodegradation of lignin (Nimz 1973; Hon and Glasser, 1979; Yazaki et al., 1994; Huang et al., 2012; Persze and Tolvaj, 2012).

Sapwood showed greater dynamics of colour change under the influence of light irradiation than heartwood (Figure 5). The value of $\Delta E$ after $300 \mathrm{~h}$ of light irradiation of non-densified sapwood was three times as high as after $20 \mathrm{~h}$ of light irradiation. The value of 


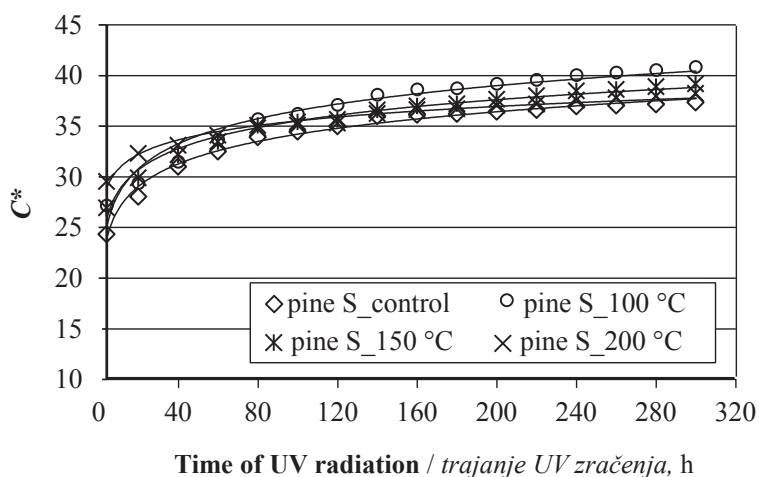

a)

Figure 6 Change in $C^{*}$ parameter of pine sapwood (a) and heartwood (b) after exposure to UV radiation Slika 6. Promjena parametra $C^{*}$ : a) bjeljike, b) srži drva bora nakon izlaganja UV zračenju

$\Delta E$ after $300 \mathrm{~h}$ of light irradiation of non-densified heartwood was double compared with its value after $20 \mathrm{~h}$ of light irradiation. The value of $\Delta E$ of non-densified sapwood after $300 \mathrm{~h}$ of light irradiation was $7 \%$ lower than in the case of non-densified heartwood and the differences were statistically significant $(p<0.05)$. The total colour difference for sapwood densified at a temperature of $100^{\circ} \mathrm{C}, 150{ }^{\circ} \mathrm{C}$ and $200^{\circ} \mathrm{C}$ was, respectively, $15 \%, 27 \%$ and $34 \%$ more substantial than the value of $\Delta E$ for heartwood densified at the same temperatures. This is due to the fact that thermo-mechanically modified pine sapwood is characterised by greater susceptibility to colour change under the influence of light irradiation than thermo-mechanically modified heartwood.

The most substantial changes in the colour of wood occurred after $20 \mathrm{~h}$ of light irradiation. A change in colour within $20 \mathrm{~h}$ accounted for about $20 \%, 30$ $\%$ and $45 \%$ of the total colour change in densified sapwood at temperatures of $100{ }^{\circ} \mathrm{C}, 150{ }^{\circ} \mathrm{C}$ and 200 ${ }^{\circ} \mathrm{C}$. Changes in colour within $20 \mathrm{~h}$ accounted for about $30 \%, 40 \%$ and $55 \%$ of the total colour difference for densified heartwood at temperatures of $100{ }^{\circ} \mathrm{C}$, $150{ }^{\circ} \mathrm{C}$ and $200{ }^{\circ} \mathrm{C}$. The higher the temperature of thermo-mechanical modification, the smaller were the values of $\Delta \mathrm{E}$ after $300 \mathrm{~h}$ of light irradiation. An exception was pine sapwood densified at $100{ }^{\circ} \mathrm{C}$ and $150{ }^{\circ} \mathrm{C}$, which was characterised by the value of $\Delta E$ similar to that of non-densified pine sapwood. Tolvaj and Mitsui (2010) noted that the differences in wood

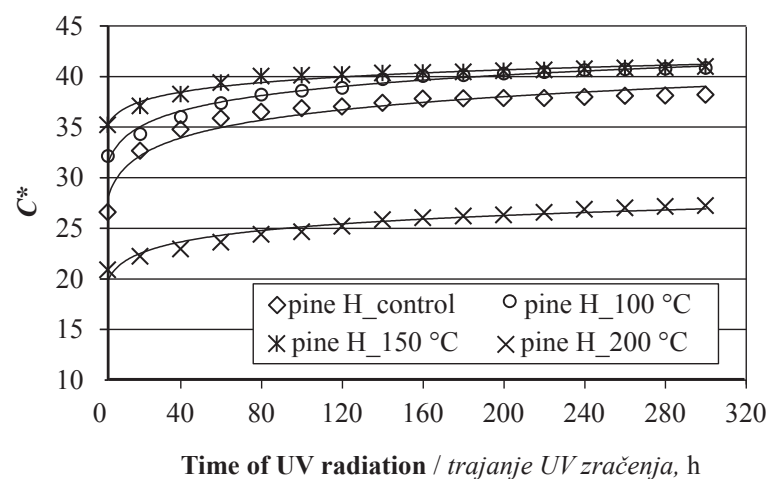

b) colour under the influence of light irradiation are due to the differences in extractive content. Pine heartwood contains more extractives than sapwood (Waliszewska et al., 2015). Ultraviolet radiation causes degradation of extractives and then also quick oxidation of degradation products, leading to a sudden drop in lightness. The modified chromophores act as an energy trap, which slows down the process of photodegradation of the main wood components (Németh et al., 1992). Therefore, the colour change of heartwood is slower than that of sapwood.

No significant differences were found between the values of $C^{*}$ for non-densified and densified pine sapwood under the influence of ultraviolet radiation (Figure 6). Similar correlations were found for pine heartwood. An exception was pine heartwood densified at $200{ }^{\circ} \mathrm{C}$. After $300 \mathrm{~h}$ of light irradiation, the value of $C^{*}$ for that heartwood was $30 \%$ lower than for non-densified heartwood. It should be noted that, after $300 \mathrm{~h}$ of light irradiation, the value of $C^{*}$ for sapwood densified at temperatures of $100{ }^{\circ} \mathrm{C}, 150{ }^{\circ} \mathrm{C}$ and $200{ }^{\circ} \mathrm{C}$ was, respectively, $50 \%, 45 \%$ and $30 \%$ higher than the value of $\mathrm{C}^{*}$ for sapwood before densification. The value of $C^{*}$ for heartwood densified at temperatures of $100{ }^{\circ} \mathrm{C}$, $150{ }^{\circ} \mathrm{C}$ and $200{ }^{\circ} \mathrm{C}$, after $300 \mathrm{~h}$ of light irradiation, was, respectively, $30 \%, 15 \%$ and $30 \%$ higher than the value of $C^{*}$ for heartwood before densification. Significant differences between the values of $C^{*}$ for sapwood and heartwood were only found when wood was densified at $200{ }^{\circ} \mathrm{C}$.
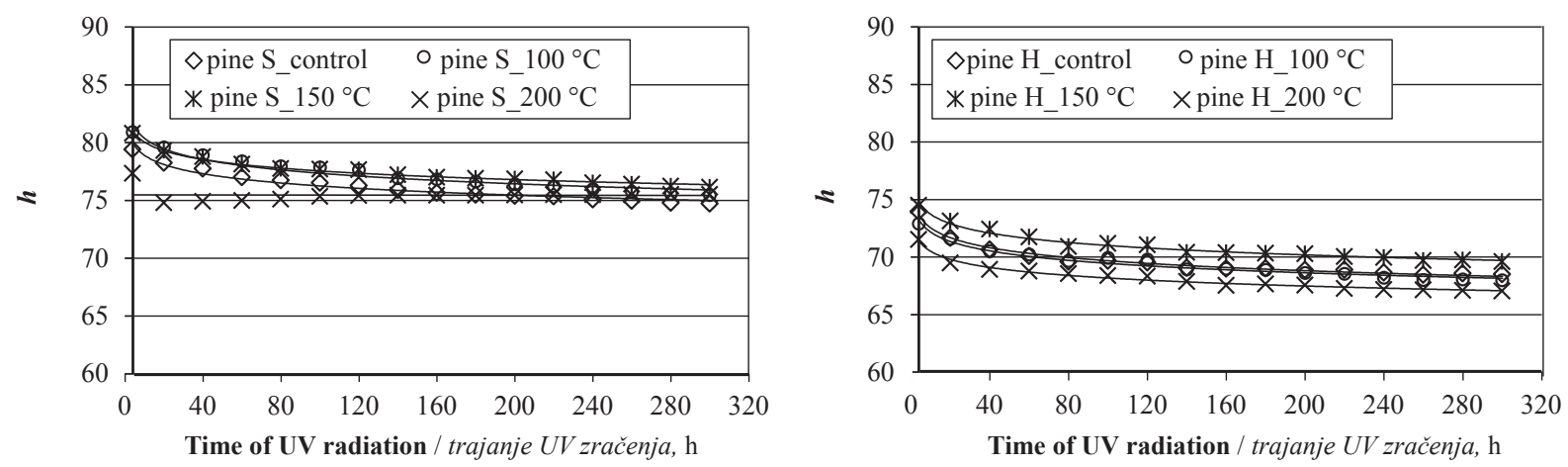

b)

Figure 7 Change in $h$ parameter of pine sapwood (a) and heartwood (b) after exposure to UV radiation

Slika 7. Promjena parametra $h$ : a) bjeljike, b) srži drva bora nakon izlaganja UV zračenju 
Table 3 Curve equations describing relations between $L^{*}, a^{*}, b^{*}, C^{*}, h, \Delta E$ and time $(t)$ of UV exposure (a - directional factor, $\mathrm{b}$ - absolute term) and $R^{2}$ - coefficient of determination)

Tablica 3. Jednadžbe krivulja koje opisuju odnose između $L^{*}, a^{*}, b^{*}, C^{*}, h, \Delta E$ i vremena $(t)$ UV zračenja (a - koeficijent smjera, b - odsječak na osi $y, R^{2}$ - koeficijent determinacije)

\begin{tabular}{|c|c|c|c|c|c|}
\hline \multirow{2}{*}{$\begin{array}{c}\text { Wood species } \\
\text { Vrsta drva }\end{array}$} & \multirow{2}{*}{$\begin{array}{c}\text { Temperature of densification } \\
\text { Temperatura procesa uguścivanja } \\
{ }^{\circ} \mathrm{C} \\
\end{array}$} & \multicolumn{4}{|c|}{ Parameters / Parametri } \\
\hline & & $a^{*}=\mathrm{a} \cdot \ln (t)+\mathrm{b}$ & $R^{2}$ & $b^{*}=\mathrm{a} \cdot \ln (t)+\mathrm{b}$ & $R^{2}$ \\
\hline \multirow{4}{*}{$\begin{array}{l}\text { pine sapwood } \\
\text { bjeljika drva } \\
\text { bora }\end{array}$} & control & $a^{*}=1.57 \cdot \ln (t)+0.88$ & 0.99 & $b^{*}=3.07 \cdot \ln (t)+18.98$ & 0.98 \\
\hline & 100 & $a^{*}=1.91 \cdot \ln (t)-0.85$ & 0.98 & $b^{*}=3.86 \cdot \ln (t)+17.73$ & 0.99 \\
\hline & 150 & $a^{*}=1.43 \cdot \ln (t)+1.01$ & 0.98 & $b^{*}=3.20 \cdot \ln (t)+19.82$ & 0.99 \\
\hline & 200 & $a^{*}=0.68 \cdot \ln (t)+6.10$ & 0.98 & $b^{*}=2.19 \cdot \ln (t)+24.13$ & 0.99 \\
\hline \multirow{5}{*}{$\begin{array}{c}\text { pine } \\
\text { heartwood } \\
\text { srž drva bora }\end{array}$} & control & $a^{*}=1.27 \cdot \ln (t)+6.99$ & 0.92 & $b^{*}=1.54 \cdot \ln (t)+27.09$ & 0.94 \\
\hline & 100 & $a^{*}=1.66 \cdot \ln (t)+5.94$ & 0.99 & $b^{*}=1.95 \cdot \ln (t)+27.10$ & 0.96 \\
\hline & 150 & $a^{*}=1.30 \cdot \ln (t)+6.94$ & 0.98 & $b^{*}=1.05 \cdot \ln (t)+32.47$ & 0.99 \\
\hline & 200 & $a^{*}=0.66 \cdot \ln (t)+11.54$ & 0.98 & $b^{*}=0.01 \cdot \ln (t)+36.40$ & 0.98 \\
\hline & & $L^{*}=\mathrm{a} \cdot \ln (t)+\mathrm{b}$ & $R^{2}$ & $\Delta E=\mathrm{a} \cdot \ln (t)-\mathrm{b}$ & $R^{2}$ \\
\hline \multirow{4}{*}{$\begin{array}{l}\text { pine sapwood } \\
\text { bjeljika drva } \\
\text { bora }\end{array}$} & control & $L^{*}=-2.01 \cdot \ln (t)+83.85$ & 0.99 & $\Delta E=3.97 \cdot \ln (t)-6.27$ & 0.98 \\
\hline & 100 & $L^{*}=-2.65 \cdot \ln (t)+88.28$ & 0.98 & $\Delta E=5.19 \cdot \ln (t)-12.57$ & 0.99 \\
\hline & 150 & $L^{*}=-1.85 \cdot \ln (t)+84.74$ & 0.97 & $\Delta E=3.90 \cdot \ln (t)-7.34$ & 0.99 \\
\hline & 200 & $L^{*}=-1.07 \cdot \ln (t)+76.44$ & 0.95 & $\Delta E=2.46 \cdot \ln (t)-3.09$ & 0.96 \\
\hline \multirow{4}{*}{$\begin{array}{c}\text { pine } \\
\text { heartwood } \\
\text { srž drva bora }\end{array}$} & control & $L^{*}=-2.32 \cdot \ln (t)+78.58$ & 0.99 & $\Delta E=3.04 \cdot \ln (t)+0.17$ & 0.99 \\
\hline & 100 & $L^{*}=-3.01 \cdot \ln (t)+80.99$ & 0.98 & $\Delta E=3.97 \cdot \ln (t)-7.99$ & 0.99 \\
\hline & 150 & $L^{*}=-1.88 \cdot \ln (t)+75.27$ & 0.99 & $\Delta E=2.57 \cdot \ln (t)-3.63$ & 0.99 \\
\hline & 200 & $L^{*}=-1.16 \cdot \ln (t)+65.54$ & 0.92 & $\Delta E=1.35 \cdot \ln (t)-0.35$ & 0.95 \\
\hline & & $C^{*}=\mathrm{a} \cdot \ln (t)+\mathrm{b}$ & $R^{2}$ & $h=\mathrm{a} \cdot \ln (t)+\mathrm{b}$ & $R^{2}$ \\
\hline \multirow{6}{*}{$\begin{array}{l}\text { pine sapwood } \\
\text { bjeljika drva } \\
\text { bora }\end{array}$} & control & $C^{*}=3.36 \cdot \ln (t)+18.69$ & 0.98 & $h=-1.37 \cdot \ln (t)+82.64$ & 0.99 \\
\hline & 100 & $C^{*}=4.39 \cdot \ln (t)+15.98$ & 0.99 & $h=-1.59 \cdot \ln (t)+84.78$ & 0.96 \\
\hline & 150 & $C^{*}=3.41 \cdot \ln (t)+19.66$ & 0.99 & $h=-1.18 \cdot \ln (t)+83.01$ & 0.98 \\
\hline & 200 & $C^{*}=2.30 \cdot \ln (t)+24.85$ & 0.98 & $h=\mathrm{a} \cdot t+\mathrm{b}$ & \\
\hline & & & & $h=0.01 \cdot t+74.94$ & 0.76 \\
\hline & & & & $h=\mathrm{a} \cdot \ln (t)+\mathrm{b}$ & $R^{2}$ \\
\hline \multirow{4}{*}{$\begin{array}{c}\text { pine } \\
\text { heartwood } \\
\text { srž drva bora }\end{array}$} & control & $C^{*}=1.91 \cdot \ln (t)+27.69$ & 0.95 & $h=-1.24 \cdot \ln (t)+75.40$ & 0.98 \\
\hline & 100 & $C^{*}=2.46 \cdot \ln (t)+27.16$ & 0.99 & $h=-1.18 \cdot \ln (t)+74.89$ & 0.97 \\
\hline & 150 & $C^{*}=1.32 \cdot \ln (t)+33.63$ & 0.92 & $h=-1.18 \cdot \ln (t)+76.43$ & 0.98 \\
\hline & 200 & $C^{*}=2.06 \cdot \ln (t)+15.70$ & 0.98 & $h=-1.01 \cdot \ln (t)+72.81$ & 0.98 \\
\hline
\end{tabular}

Changes in the value of $\mathrm{h}$ under the influence of light irradiation for sapwood and heartwood were logarithmic. An exception was pine sapwood densified at $200{ }^{\circ} \mathrm{C}$ (Figure 7). After $300 \mathrm{~h}$ of light irradiation of non-densified sapwood and sapwood densified at 100 ${ }^{\circ} \mathrm{C}$ and $150{ }^{\circ} \mathrm{C}$, a $6 \%$ decrease in the value of $\mathrm{h}$ was recorded as compared to the wood before light irradiation. In the case of non-densified and densified heartwood, a $7 \%$ decrease in the value of $h$ was recorded after $300 \mathrm{~h}$ of light irradiation as compared to the wood before light irradiation. The differences were statistically significant $(p<0.05)$. In general, it can be concluded that, after $300 \mathrm{~h}$ of light irradiation, the value of $\mathrm{h}$ for sapwood was $10 \%$ higher than the value of $\mathrm{h}$ recorded for heartwood, irrespective of the modification temperature.

Table 3 presents a summary of equations of the straight lines showing the correlations between the wood colour parameters and the values of the coefficient of determination $\mathrm{R}^{2}$. The high values of $R^{2}$, close to "1", indicate the usefulness of the regression equation for anticipating the value of the dependent variable $\mathrm{L}^{*}, a^{*}, b^{*}, C^{*}, h$ and $\Delta E$ using the independent variable $t$, which is the wood light irradiation time.
Regression equations of colour parameters for pine wood densified throughout the range of temperatures and light irradiation is presented in Table 4. The $R^{2}$ values show that a change in colour parameters is much more pronounced for pine sapwood than pine heartwood. In the case of pine heartwood, the coefficient of determination $R^{2}$ was less than 0.50 for four out of nine determined correlations. The correlations between the colour parameters of pine sapwood were found to have the value of $R^{2}$ greater than 0.61 . The best linear correlation was found between $C^{*}$ and $b^{*}$ for pine sapwood $\left(R^{2}=0.99\right)$ as well as heartwood $\left(R^{2}\right.$ $=0.93)$. A high correlation was also found between $h$ and $a^{*}$ for pine sapwood $\left(R^{2}=0.97\right)$ and heartwood $\left(R^{2}\right.$ $=0.92)$. This means that only the values of $b^{*}$ and $a^{*}$ can be used to determine the values of $C^{*}$ and $h$, respectively, (Figure 8).

\section{CONCLUSIONS 4. ZAKLJUČAK}

On the basis of the present study, it has been found that ultraviolet radiation has a significant influence on the colour of thermo-mechanically modified 
Table 4 Regression equations of colour parameters for pine sapwood and heartwood samples densified at all investigated ranges of temperature and light irradiation

Tablica 4. Regresijske jednadžbe parametara boje uzoraka od bjeljike i srži drva bora nakon procesa ugušćivanja pri svim istraživanim temperaturama i UV zračenjima

\begin{tabular}{|l|l|l|c|}
\hline \multicolumn{4}{|c|}{ Area of pine wood / Dio drva bora } \\
\hline \multicolumn{1}{|c|}{ Sapwood / Bjeljika } & & \multicolumn{1}{c|}{ Heartwood / Srž } & \\
\hline Function & $R^{2}$ & Function & $R^{2}$ \\
\hline$a^{*}=-0.62 \cdot L^{*}+54.96$ & 0.88 & $a^{*}=-0.46 \cdot L^{*}+43.98$ & 0.66 \\
\hline$b^{*}=-1.18 \cdot L^{*}+124.64$ & 0.75 & $b^{*}=-0.23 \cdot L^{*}+51.83$ & 0.23 \\
\hline$\Delta E=-1.33 \cdot L^{*}+111.98$ & 0.61 & $\Delta E=-0.30 \cdot L^{*}+29.54$ & 0.09 \\
\hline$C^{*}=-1.29 \cdot L^{*}+133.78$ & 0.77 & $C^{*}=-0.37 \cdot L^{*}+63.70$ & 0.41 \\
\hline$C^{*}=2.19 \cdot a^{*}+18.66$ & 0.95 & $C^{*}=0.77 \cdot a^{*}+28.90$ & 0.57 \\
\hline$C^{*}=1.08 \cdot b^{*}-1.82$ & 0.99 & $C^{*}=1.17 \cdot b^{*}-3.71$ & 0.93 \\
\hline$h=0.56 \cdot L^{*}+35.04$ & 0.94 & $h=0.52 \cdot L^{*}+35.36$ & 0.60 \\
\hline$h=-0.87 \cdot a^{*}+84.24$ & 0.97 & $h=-1.15 \cdot a^{*}+85.36$ & 0.92 \\
\hline$h=-0.39 \cdot b^{*}+90.90$ & 0.84 & $h=-0.41 \cdot b^{*}+84,87$ & 0.08 \\
\hline
\end{tabular}

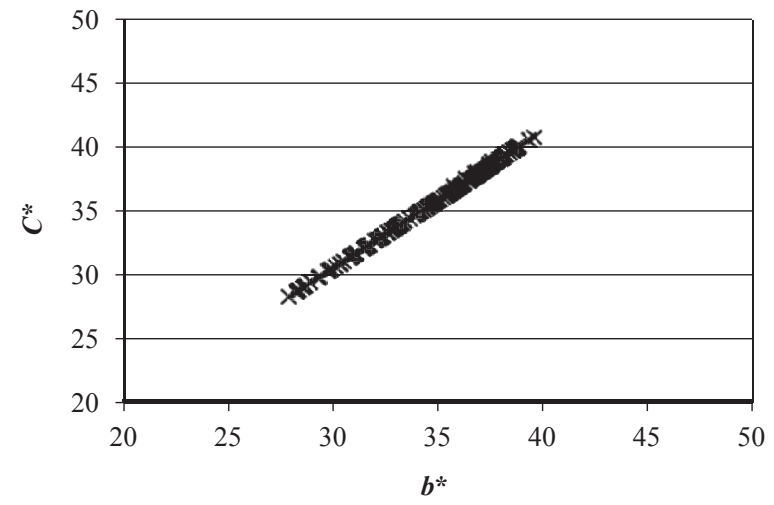

a) pine sapwood $C^{*}\left(b^{*}\right) /$ bjeljika drva bora

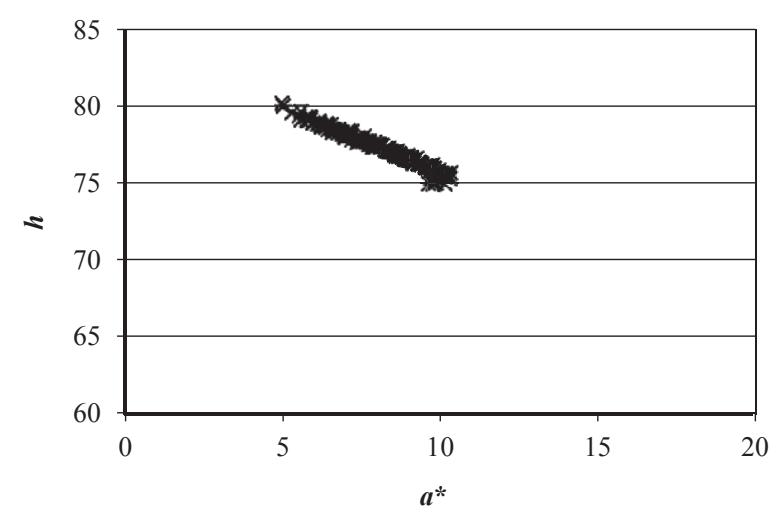

c) pine sapwood $h\left(a^{*}\right)$ / bjeljika drva bora

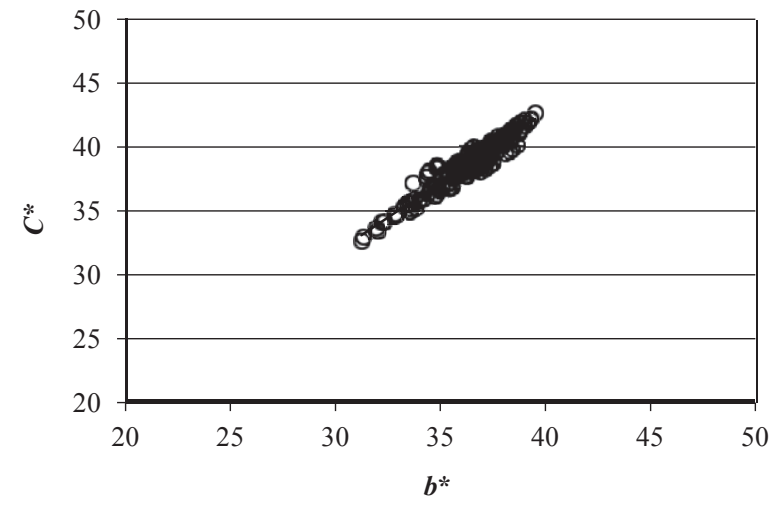

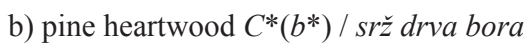

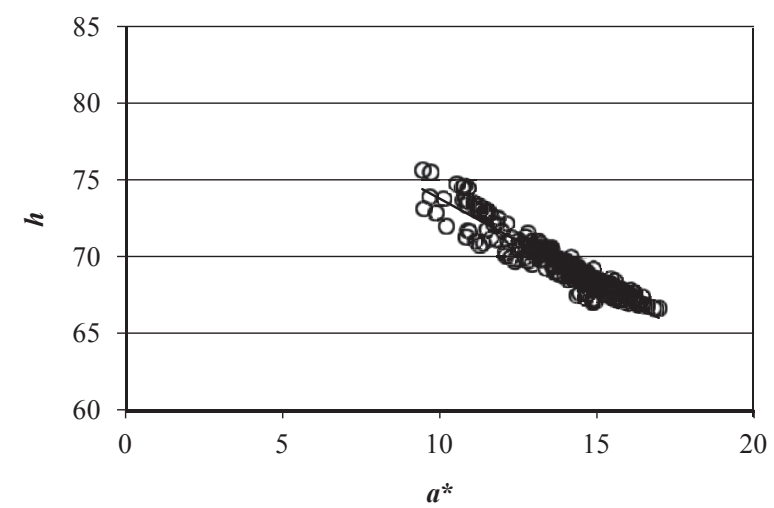

d) pine heartwood $h\left(a^{*}\right) / \operatorname{srž}$ drva bora

Figure 8 Correlation between colour parameters for pine sapwood and heartwood samples densified at all investigated ranges of temperature and light irradiation

Slika 8. Korelacija između parametara boje uzoraka od bjeljike i srži drva bora nakon procesa ugušćivanja pri svim istraživanim temperaturama i UV zračenjima

pine sapwood and heartwood. The higher the temperature of thermo-mechanical modification, the smaller was the degree of colour change of wood under the influence of ultraviolet radiation. This was due to chemical changes in wood during the treatment. Changes in lightness occurring within $20 \mathrm{~h}$, irrespective of the temperature of treatment, accounted for about $30-60$
$\%$ of the total change in pine sapwood and heartwood. Sapwood showed greater dynamics of colour change under the influence of light irradiation than heartwood. Thermo-mechanically modified pine sapwood is characterised by greater susceptibility to colour change under the influence of light irradiation than thermo-mechanically modified heartwood. 


\section{REFERENCES}

\section{LITERATURA}

1. Bekhta, P.; Niemz, P., 2003: Effect of high temperature on the change in colour, dimensional stability and mechanical properties of spruce wood. Holzforschung, 57 (5): 539-546. https://doi.org/10.1515/HF.2003.080

2. Bekhta, P.; Proszyk, S.; Krystofiak, T., 2014: Colour in short term thermo-mechanically densified veneer of various wood species. European Journal of Wood and Wood Products, 72 (6): 785-797. https://doi.org/10.1007/s00107-014-0837-1

3. Diouf, P. N.; Stevanovic, T.; Cloutier, A.; Fang, Ch.-H.; Blanchet, P.; Koubaa, A.; Mariotti, N., 2011: Effects of thermo-hygro-mechanical densification on the surface characteristics of trembling aspen and hybrid poplar wood veneers. Applied Surface Sciences, 257 (8): 35583564. https://doi.org/10.1016/j.apsusc.2010.11.074

4. Gierlinger, N.; Jacques, D.; Grabner, M.; Wimmer, R.; Schwanninger, M.; Rozenberg, P.; Paques, L. E., 2004: Colour of larch heartwood and relationships to extractives and brown-rot decay resistance. Trees, 18 (1): 102108. https://doi.org/10.1007/s00468-003-0290-y

5. González-Peña, M. M.; Hale, M. D. C., 2009: Colour in thermally modified wood of beech, Norway spruce and Scots pine. Part 2: property prediction from colour changes. Holzforschung, 63 (4): 394-401. https://doi.org/10.1515/hf.2009.077

6. Hon, D. N.-S.; Glasser, W., 1979: On possible chromophoric structures in wood and pulps. A survey of the present state of knowledge. Polymer-Plastics Technology and Engineering, 12 (2): 159-179.

https://doi.org/10.1080/03602557908067670

7. Hon, D. N.-S.; Minemura, N., 1991: Color and Discoloration. U: D. N.-S. Hon; N. Shiraishi (ed.): Wood and Cellulose Chemistry. New York, Marcel Dekker Inc., pp. 395-454.

8. Huang, X.; Kocaefe, D.; Kocaefe, Y.; Boluk, Y.; Pichette, A., 2012: A spectrocolorimetric and chemical study on color modification of heat-treated wood during artificial weathering. Applied Surface Science, 258 (14): 53605369. https://doi.org/10.1016/j.apsusc.2012.02.005

9. Johansson, D.; Morén, T., 2006: The potential of colour measurement for strength prediction of thermally treated wood. Holz als Roh- und Werkstoff, 64 (2): 104-110. https://doi.org/10.1007/s00107-005-0082-8

10. Kollmann, F.; Fengel, D., 1965: Änderungen der chemischen Zusammensetzung von Holz durch thermische Behandlung. Holz als Roh- und Werkstoff 23: 461. https://doi.org/10.1007/BF02627217

11. Laine, K.; Belt, T.; Rautkari, L.; Ramsay, J.; Hill, C. A. S.; Hughes, M., 2013: Measuring the thickness swelling and set-recovery of densified and thermally modified Scots pine solid wood. Journal of Materials Science 48 (24): 8530-8538. https://doi.org/10.1007/s10853-013-7671-4

12. Laine, K.; Segerholm, K.; Wålinder, M.; Rautkari, L.; Hughes, M., 2016: Wood densification and thermal modification: Hardness, set-recovery and micromorphology. Wood Science and Technology, 50 (5): 883-894. https://doi.org/10.1007/s00226-016-0835-z

13. Laskowska, A., 2017: The influence of process parameters on the density profile and hardness of surface-densi- fied birch wood (Betula pendula Roth). BioResources, 12 (3): 6011-6023.

https://doi.org/10.15376/biores.12.3.6011-6023

14. Moya, R.; Fallas, R. S.; Bonilla, P. J.; Tenorio, C., 2012: Relationship Between Wood Color Parameters Measured by the CIELab System and Extractive and Phenol Content in Acacia mangium and Vochysia guatemalensis from Fast-Growth Plantations. Molecules, 17 (12): 3639-3652.

https://doi.org/10.3390/molecules17043639

15. Nimz, H. H., 1973: Chemistry of potential chromophoric groups in beech lignin. Tappi Journal, 56 (5): 124-126.

16. Németh, K.; Vanó, V.; Faix, O., 1992: The effect of wood extractives on the photodegradation of wood. In: EWLP conf., Grenoble, France, 191-192.

17. Pandey, K. K., 2005: A note on the influence of extractives on the photo-discoloration and photo-degradation of wood. Polymer Degradation and Stability, 87 (2): 375 379.

https://doi.org/10.1016/j.polymdegradstab.2004.09.007

18. Persze, L.; Tolvaj, L., 2012: Photodegradation of wood at elevated temperature: Colour change. Journal of Photochemistry and Photobiology B: Biology, 108: 44-47. https://doi.org/10.1016/j.jphotobiol.2011.12.008

19. Rautkari, L.; Laine, K.; Kutnar, A.; Medved, S.; Hughes, M., 2013: Hardness and density profile of surface densified and thermally modified Scots pine in relation to degree of densification. Journal of Materials Science, 48 (6): $2370-2375$ https://doi.org/10.1007/s10853-012-7019-5

20. Sandermann, W.; Augustin, H., 1963: Chemische Untersuchungen über die thermische Zersetzung des Holzes. Erste Mitteilung: Stand der Forschung. Holz als Rohund Werkstoff, 21: 256-265.

https://doi.org/10.1007/BF02616316

21. Sharratt, V.; Hill, C. A. S.; Kint, D. P. R., 2009: A study of early colour change due to simulated accelerated sunlight exposure in Scots pine (Pinus sylvestris). Polymer Degradation and Stability, 94 (9): 1589-1594. https://doi.org/10.1016/j.polymdegradstab.2009.04.010

22. Tolvaj, L.; Mitsui, K., 2010: Correlation between hue angle and lightness of light irradiated wood. Polymer Degradation and Stability, 95 (4): 638-642. https://doi.org/10.1016/j.polymdegradstab.2009.12.004

23. Tu, D.; Su, X.; Zhang, T.; Fan, W.; Zhou, Q., 2014: Thermo-mechanical densification of Populus tomentosa var. tomentosa with low moisture content. BioResources, 9 (3): 3846-3856. https://doi.org/10.15376/biores.9.3.3846-3856

24. Ülker, O.; İmirzi, Ö.; Burdurlu, E., 2012: The effect of densification temperature on some physical and mechanical properties of Scots pine (Pinus sylvestris L.). BioResources, 7 (4): 5581-5592.

https://doi.org/10.15376/biores.7.4.5581-5592

25. Wagenführ, R., 2007: Holzatlas. Fachbuchverlag Leipzig im Carl Hanser Verlag, München, Germany.

26. Waliszewska, B.; Prądzyński, W.; Zborowska, M.; Stachowiak-Wencek, A.; Waliszewska, H.; Spek-Dźwigała, A., 2015: The diversification of chemical composition of pine wood depending on the tree age. Annals of Warsaw University of Life Sciences - SGGW. Forestry and Wood Technology, 91: 182-187.

27. Yazaki, Y.; Collins, P. J., Mccombe, B., 1994: Variations in hot water extractives content and density of commer- 
cial wood veneers from blackbutt (Eucalyptus pilularis). Holzforschung, 48 (s1): 107-111. https://doi.org/10.1515/hfsg.1994.48.s1.107

28. *** ISO 7724-3, 1984: Paints and varnishes - Colorimetry - Part 3: Calculation of colour differences. International Organization for Standardization, Geneva, Switzerland.

29. *** ISO 13061-1, 2014: Physical and mechanical properties of wood - Test methods for small clear wood specimens - Part 1: Determination of moisture content for physical and mechanical tests. International Organization for Standardization, Geneva, Switzerland.

30. *** ISO 13061-2 2014: Physical and mechanical properties of wood - Test methods for small clear wood specimens - Part 2: Determination of density for physical and mechanical tests. International Organization for Standardization, Geneva, Switzerland.

\section{Corresponding address:}

Assist. prof. AGNIESZKA LASKOWSKA Ph.D.

Department of Wood Sciences and Wood Preservation Faculty of Wood Technology

Warsaw University of Life Sciences - SGGW

Nowoursynowska 159 St.

02 - 776 Warsaw, POLAND

e-mail: agnieszka_laskowska@sggw.pl 